\title{
Bamboo: An Alternative Raw Material for Wood and Wood-Based Composites
}

\author{
Pannipa Chaowana ${ }^{1}$ \\ ${ }^{1}$ School of Engineering and Resources, Walailak University, Nakorn Sri Thammarat, Thailand \\ Correspondence: Dr. Pannipa Chaowana, School of Engineering and Resources, Walailak University, Nakorn Sri \\ Thammarat 80160, Thailand. Tel: 66-7567-2312. E-mail: mpannipa@wu.ac.th
}

Received: February 17, 2013 Accepted: March 5, 2013 Online Published: March 15, 2013

doi:10.5539/jmsr.v2n2p90 URL: http://dx.doi.org/10.5539/jmsr.v2n2p90

\begin{abstract}
Bamboo is the most important non-wood species which is abundantly grows in most of the tropical and subtropical zone. It has developed as a specially valuable and superior alternate for wood composite manufactured, such as for pulp and paper, stripboards, matboards, veneer, plywood, particleboard and fiberboard. Moreover, several researches have used it as raw material for structural composites such as Oriented Strand Board (OSB), Glue Laminated Timber (GLT), Parallel Strip Lumber (PSL) and Oriented Strand Lumber (OSL). Nowadays, there are many kinds of bamboo composite are produced and traded in the world. However, there are several differences between bamboo and wood for example macroscopic and microscopic characteristics, chemical composition, physical and mechanical properties. For this reason, the methods, technology and equipment for wood processing cannot be directly applied in bamboo utilization. Further research is noticeably required on the information on bamboo properties, cost-effective technologies and managements. With modern techniques and adapted technologies, bamboo can be processed into a wide range of products which successfully compete with wood and other raw materials in the future.
\end{abstract}

Keywords: bamboo, alternative raw material, wood-based composites

\section{Introduction}

With the rapid development of the global economy and constant increase in population, the overall demand for wood and wood based composites is rising, while the available wood supply will decrease due to the global biomass demands for the green energy generation. Consequently, the search for alternative raw materials in place of wood has been come into focus. A suitable raw material should be inexpensive, fast-growing, easily available having comparable physical and mechanical properties to the wood, and also it should be compatible to the existing processing technologies. Bamboo could be such the alternative raw material.

Bamboo is one of the oldest building materials used by mankind in tropical and subtropical regions. The bamboo culms have been widely used in building applications, such as flooring, ceiling, walls, windows, doors, fences, housing roofs, trusses and rafters; it is also used in construction as structural materials for bridges, water-transportation facilities and skyscraper scaffoldings. In addition, it has been also processed into an extended diversity of products ranging from domestic household products such as food containers, skewers, chopsticks, handicrafts, toys, furniture, flooring, boats, charcoal, musical instruments and weapons. In rural areas, bamboo is called the poor man's timber due to the entire aspects of bamboo utilization in the human life.

Since the $20^{\text {th }}$ century, bamboo has received increasing attention for industrial applications, especially as raw material for wood-based composites such as particleboard (PB), medium density fiberboard (MDF), hard fiberboard (HB), plywood, oriented strand board (OSB), zephyr board, laminated bamboo lumber, parallel strand lumber (PSL) and oriented strand lumber (OSL), inorganic-bonded board (i.e., cement), wood plastic composites (WPC), because of its fast growing nature, high productivity, quick maturity and high strength with an advance in processing technology and increased market demand.

This review evaluates the suitability of bamboo as the alternative raw material for wood composite products, and tackles about the fact of bamboo, distribution of bamboo resources, bamboo situation in the world, its extraordinary productivity and uses, etc. These basic data are important in formulating effective bamboo resource policies and its utilization. 


\section{What Is Bamboo?}

Bamboo is the common name for member of a particular taxonomic group of a perennial grass with large woody stem or culm belonging to the family Poaceae, subfamily Bambusoideae. It encompasses about 1,200 species within 50 genera (Chapman, 1996; Zhang et al., 2002).

\section{Bamboo Morphology}

The major morphological characteristic of bamboo is divided into the rhizome and the culm system (Zhang et al., 2002; Jiang, 2007).

\subsection{Rhizome System}

The rhizome or subterranean stem is initiated the underground part of bamboo. It constitutes the modified structural foundation of a bamboo plant. In the viewpoint of functional work, rhizome serves for the uptake, transport, distribution and storage of water and nutrients, which function of parenchyma and conduction tissue, as well as for the vegetative production by growing into the new shoots or bamboo culms at their nodes.

\subsection{Culm System}

The culm is the upper ground part of bamboo that contains most of the woody material. It is complimented by a branching system, sheath, foliage leaves, flowering, fruits and seedlings. Bamboo culm develops in one period of growth by a delicately timed process of cell elongation, with some cell division as well. When the new culms appear, they already have attained their ultimate diameter. Unlike trees, bamboos have no secondary thickening growth. Normally, the culm is straight, hollow and cylinder-formed with nodes and internode parts.

\section{Bamboo Growth}

Bamboo is a fast growing species and a high yield renewable resource. It growth depends on species, but generally all bamboo matures quickly. The fast growth characteristic of bamboo is an important incentive for its utilization.

Unlike trees, bamboos grow to full height and girth in a single growing season. Zhang et al. (2002) described that the height growth of bamboo culm is realized by the internodes growth. The cell division varies with the difference internode location. The speed of growth is also different in internodes. After the end of height growth, the height, thickness and volume of bamboo stems do not change. Consequently, the maturity process begins. In this duration, cell wall thickens and specific gravity increases, moisture content decreases and physical and mechanical properties increase.

Bamboo can reach its maximum height in 4 to 6 months with a daily increment of 15 to $18 \mathrm{~cm}$. It might have 40 to 50 stems in one clump, which adds 10 to 20 culms yearly (Aminuddin, \& Abd. Latif, 1991). In addition, bamboo culms take 3 to 6 years to mature, which depends on the species. Therefore, bamboo growth is more rapid than any other plant of this size on the planet (Lee \& Perry, 1994; Wong, 1995).

\section{World Bamboo Resources}

The total bamboo area in the world is approximately 36 million hectares or an average of $3.2 \%$ of the total forest area. It is naturally distributed in the tropical and subtropical zone at latitudes from approximately $46^{\circ}$ North to $47^{\circ}$ South latitude, and from sea level to as much as 3,000 meters in elevation where has a warm climate, abundant moisture, and productive soil. In naturally, bamboo is mostly distributed in the tropics, subtropical and temperate zones of all continents except Europe and North America. In recent years, bamboo is introduced into North America, Europe and Australia. (Lobovikov, Paudel, Piazza, Ren, \& Wu, 2007; Zhang et al., 2002; Jiang, 2007).

\subsection{Asia and Oceania}

This region is the richest bamboo producer with about $65 \%$ of total world bamboo resources or approximately 24 million hectares (Jiang, 2007). There are about nearly 900 species and about 40 to 50 genera, accounting for about $80 \%$ of bamboo species in the world. Interestingly, the five of the six countries, where are the largest extent of bamboo forests, are in Asia; India, China, Indonesia, Myanmar and Vietnam. Additionally, Southeast Asia has been postulated to be the bamboo origin presents the center of bamboo distribution. Around $80 \%$ of bamboo species are sympodial type, and all the rest of it is monopodial type. More or less 250 bamboo species are high economic valuable in different aspects, such as construction, handicraft, food and industrial purposes, such as Bambusa bambos, B. blumeana, Dendrocalamus asper, D. giganteus, D. strictus, Phyllostachys heterocycla and Ph. bambusoides.

India is the major bamboo producing country, possessing about 145 species; the area of bamboo growth exceeds 11.4 million ha or one surface covered by bamboo and $17 \%$ of the country's total forest area. Another major 
bamboo-producing country is China having the highest bamboo biodiversity in Asia, with over 500 species, covering 5.4 million ha or about $3 \%$ of its total forested area. Interestingly, the bamboo area in China has been rapidly increasing of about 50,000 hectares per year. Moso bamboo (Ph. heterocycla), the most important bamboo species with high economic value, covers an area of 3.4 million hectares or about $70 \%$ of total bamboo area in China (Lobovikov et al., 2007).

Over $80 \%$ of Asian forests including bamboo forest are public areas, which are under the formal jurisdiction of governments and forest management is mostly a governmental issue (Lobovikov et al., 2007). From 1990-2000, the total bamboo resources in Asia increased approximately $7 \%$ but the public ownership of bamboo resources decreased from 81 to $73 \%$. It can be explained by a greater rate of private ownership bamboo resource increased, especially in China where one-third of the bamboo forests were private ownership and promotes bamboo as a new material for industrial uses. Interestingly, the new ownership structure in China cooperated between the government and farmers. The farmers could rent the public land for up to 50 years and planted bamboo belonging to farmers. This system has enhanced production opportunities and market of bamboo.

\subsection{Latin America}

In Latin America, bamboo occupies 10 million hectares or $28 \%$ of the total bamboo area in the world. According to Jiang (2007), there are around 270 bamboo species within 18 genera which mostly are monopodial bamboos. However, Guadua spp. is the most well-known bamboo species because it has a large culm favorably used in construction and industry.

\subsection{Africa}

Africa has the smallest bamboo area covering an area of 2.7 million hectares or $7 \%$ of the total bamboo area in the world. There are totally about 40 species within 13 genera which mostly distribute in tropical rainforest and evergreen broadleaved mixed forest. The main species are Arundinaria alpine, B. vulgaris and Oxytenanthera abyssinica. In the African, approximately 66 percent of bamboo area is classified as private system. Compared with Asia, the level of bamboo utilization and development in Latin America and Africa are far lower. It can be represented by the consistence rate of bamboo area during 1990 to 2005 (Lobovikov et al., 2007).

It seems to be that bamboo could be a non-wood alternative material for the tropical and subtropical regions. There are 2.5 billion people in Asia, over 40\% of the world's population, use bamboo for fiber and food in everyday. Moreover, it becomes the substitute materials in place of wood for the wood composite industries. Subsequently, the bamboo properties which are important factors to determine its utilization are reviewed in the next part.

\section{Bamboo Utilization as Alternative Wood Materials.}

Bamboo utilization as alternative wood materials may be divided up into following broad categories:

\subsection{Construction}

Bamboo is a major building material in many countries, particularly in Asia, Africa and South America, because of its strong characteristics, light weight and flexible properties. It can be used for almost all parts of houses, including posts, roofs, walls, floors, beams and trusses.

\subsection{Household Products}

These include agricultural instruments, fishing tools, handicrafts, musical instruments, furniture, crafts and woven mats.

\subsection{Food}

About 200 species of bamboo, a well-known feature of Chinese and other Asian cuisines can provide suitable shoots for eating. Fresh bamboo shoots are delicious and healthy, with high fiber content.

\subsection{Charcoal}

Bamboo charcoal is traditionally used as a substitute for wood charcoal or mineral coal. It can serve as a fuel, for cleaning drinking water, cooking, bathing, improving soil, regulating room humidity, preserving freshness of vegetables, fruits and flowers, deodorizing, for conducting electricity, etc.

\subsection{Pulp and Paper}

Because bamboo fibers are relatively long, thus it can be used for paper production. Bamboo paper has practically the same quality as paper made from wood. Its brightness and optical properties remain stable.

\subsection{Composite Boards}

The use of bamboo in composite boards overcome differences in quality related to the culms. These allow the 
production of homogeneous products. The panels are widely used in modern construction as structural elements or as forms for concrete moldings. They are also used for flooring, roofing, partitions, doors and window frames. Bamboo panels have some advantages over wooden boards due to their rigidity and durability.

\section{Bamboo Properties and Suitability as an Alternative Raw Material for Wood Composites}

Bamboo is a lingo-cellulosic material like wood. Moreover, both of them are heterogeneous and anisotropic material. Nevertheless, there are several different characteristics between bamboo and wood. Consequently, the methods, technology and equipment for wood processing cannot be applied indiscriminately in bamboo utilization. Thus, it is necessary to understand and apply them thoroughly for successful utilization of bamboo for wood composite manufacture.

\subsection{The Macroscopic Characteristic of Bamboo Culm}

The bamboo culm is the upper ground part of bamboo that contains most of the woody material. The culm is straight, hollow and cylinder-formed with nodes and internodes which are the parts between nodes. In the internodes, the cells are strongly oriented axially. No radial cell elements exist and therefore, the transversal interconnection is provided only by the nodes with their solid cross wall, called diaphragm. The variation between internode and node is not desirable characteristics which have an effect on the penetration of liquid adhesive used for bonding the bamboo elements together. In addition, the node part shows higher specific gravity, less dimensional stability and lower mechanical properties. Moreover, nodes cause damage or rapid wear of equipments. Although nodes are not desirable in bamboo utilization, especially for bamboo composites, they cannot be separated from internodes. In processing and utilizing of bamboo culm should be closely considered to this problem.

The bamboo macroscopic characteristics vary along the culm height. The variation of macroscopic characteristics of bamboo along the culm length is shown in Figure 1. The internode length, diameter and wall thickness of bamboo culm vary in accordance to the culm position. The internode length increases from the bottom to the middle part and decreases toward the top part. The maximum internode length is located in the $1 \mathrm{st}$ third of the culm. The culm diameter decreases from the bottom to the top. Bamboo culms taper towards the top with a gradual decrease in diameter. The culm wall thickness significantly decreases with height.

Due to the thick wall and long culm, bamboo can be processed into many forms of particles, such as flour, fibers, flakes, chips, excelsior, strips, strands and veneer. Moreover, bamboo has a long straight grain which can compensate the potential shortcoming. It can easily be cut into thin and long pieces, such as excelsior, strips, strands and veneers. The diameter of bamboo culm is smaller than those of wood species. The smallest bamboo species, Raddiella vanessiae, can grow as little as $2 \mathrm{~cm}$ in height (Judziewicz \& Sepsenwol, 2007) while the largest known D. giganteus grow up to $60 \mathrm{~m}$ in height and $20 \mathrm{~cm}$ in culm diameter (Rao, Ramanatha-Rao, \& Williams, 1998). Additionally, the culm diameter extremely varies along the culm length. The culms taper towards the top with a gradual decrease in diameter. Then, the bamboo processing might be applied with the high efficient method and equipment of woodworking industry.

On both sides of bamboo culm wall are covered by a special tissue. The outermost skin of the bamboo culm consists of epidermal cells that are covered with a waxy layer poor affinity of water and adhesives. The innermost skin or pith is the part of culm wall next to culm cavity. It is composed of sclerenchyma cells. Such this characteristic leads to negative influences on adhesion. 


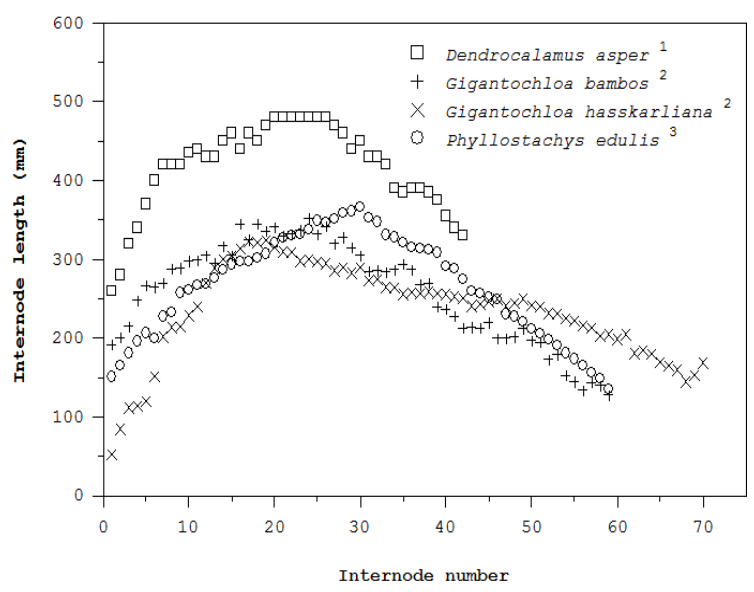

(a)

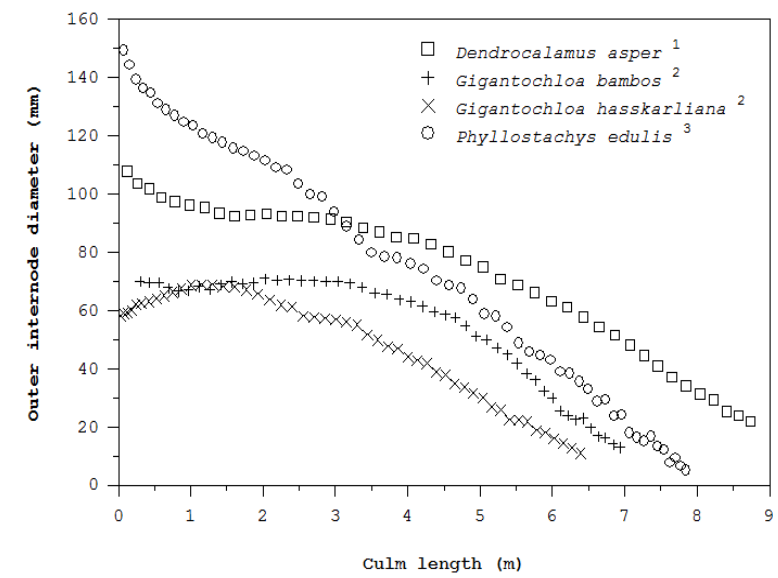

(b)

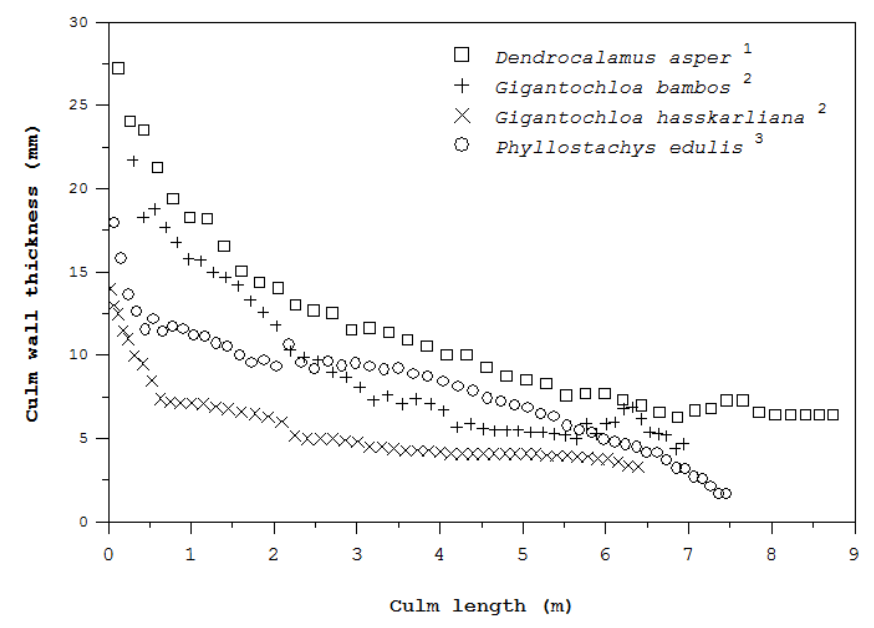

(c)

Figure 1. Variation of macroscopic characteristics along the height of four bamboo species for (a) internode length, (b) outer internode diameter and (c) culm wall thickness

Source:

${ }^{1}$ Malanit, Barbu, Liese, and Frühwald (2008)

${ }^{2}$ Sutnaun et al. (2005)

${ }^{3}$ Amada and Untao (2001) 


\subsection{The Microscopic Characteristic of Bamboo Culm}

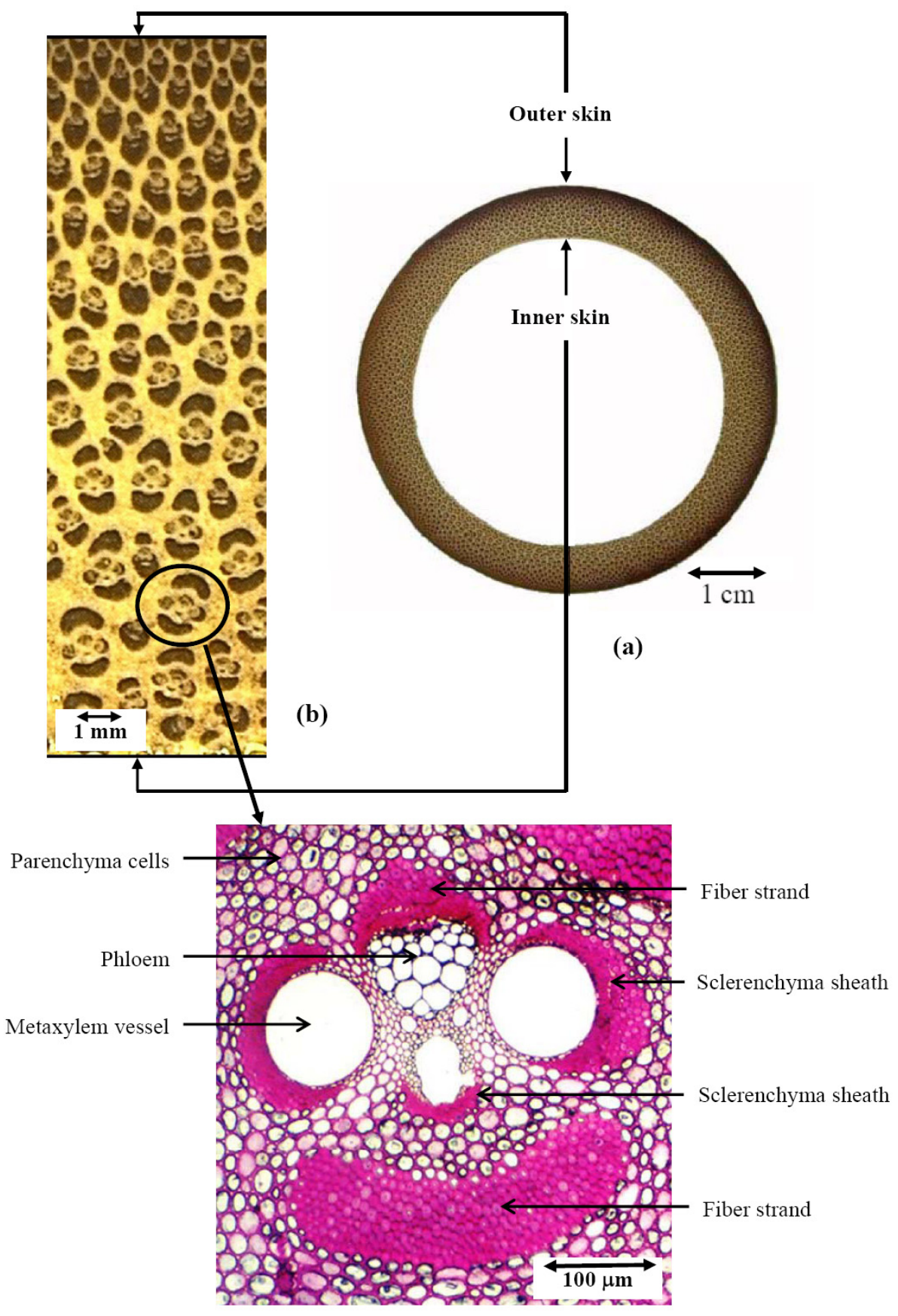

Figure 2. Microstructure of $D$. asper for (a) culm circular cross-section, (b) distribution of vascular bundles from the outer to the inner surface, and (c) parenchyma cells and vascular bundle which consists of vessels, phloem and fiber

The structure of a bamboo culm transverse section is characterized by numerous vascular bundles embedded in the parenchymatous ground tissue, as presented in Figure 2. The total culm tissue consists of $50 \%$ parenchyma, $40 \%$ fibers and $10 \%$ conducting cells (Liese, 1998). The percentage distribution shows a specific pattern within the culm, both horizontally and vertically. The parenchyma and conducting cells are more frequent in the inner third of the wall, while the percentage of fiber is higher in the outer part. In the vertical direction, the fiber amount increases from bottom to top with the decreasing parenchyma content. Many studies have been 
published on the anatomical features of bamboo which directly affect the physical and mechanical properties (Abd. Latif, Ariffin, \& Ahmad, 1990; Abd. Latif, Ashaari, Jamaludin, \& Mohd. Zin, 1993; Grosser, \& Liese, 1971). It is expected that these features may affect the bamboo processing and utilization.

The bamboo fibers are sclerenchymatous tissue with thicker wall, long and tapered at their ends. The ratio of length to width varies between 150:1 and 250:1. They occur in the internodes as caps of the vascular bundles and sheaths around the vessels, as present in Figure 2. They contribute $40-50 \%$ of the total culm tissue. Then, they were suggested to be the sustainable raw material for the fiber composite products. In accordance with Grosser and Liese (1971) and Liese (1998), the fiber length of bamboo varies from 2 to $4 \mathrm{~mm}$. Compared to some wood species (Fengel \& Wegener, 1984), the bamboo fiber length is quite similar to that of softwood tracheids. Therefore, bamboo can be used as an alternative raw material for pulp and paper industries. Many studies have evaluated the properties of bamboo fiber-based composites such as medium density fiberboard (Bauchongkol, Hiziroglu, Fueangvivat, Jarusombuti, \& Soontonbura, 2009; Zhang, Kawai, Yusuf, Imamura, \& Sasaki, 1997) and hardboard (Lee, Shupe, \& Hse, 2006; Laemsak \& Kungsuwan, 2000; Shao, Wen, \& Jin, 2008; Shao, Jin, Wen, \& Iiyama, 2009). They concluded that bamboo fibers can be used to produce bamboo-fiber composites with accepted physical and mechanical properties.

\subsection{The Gluability Properties of Bamboo Culm}

In wood composite manufacture, adhesive is required to bond wood element together. The adhesive is not only a significant cost factor in wood composite production but also it is the key factor for some of the product properties. The gluability of bamboo is influenced by its surface properties, such as wettability, $\mathrm{pH}$ value, buffering capacity etc.

Ahmad and Kamke (2003), Anwar, Paridah, Hamdan, Abd. Latif and Zaidon (2005), Chaowana, Robkorb, Sriwilai, and Barbu (2012) reported that the average contact angle of D. strictus, Gigantochloa scortechinii and $D$. asper is 52,14 and $35^{\circ}$, respectively. They are slightly lower than that of common wood species such as Aspen, Yellow-poplar and White Oak which are normally used in wood composite manufacturer (Freeman, \& Wangaard, 1960). They mentioned that bamboo wettability decreases from the bottom to the top part of the culm. Furthermore, wettability of bamboo culm outer surface is found to be lower than inner part. It can be seen that the contact angle of the outer surface is higher than that of the inner surface suggested that this one is easier to be wetted than the outer one. Usually, the material with a higher contact angle has poor surface wettability resulted in poor bonding because of greater tendency for starved joints. It can be confirmed by the decreasing of bonding strength of bamboo boards which were laid in outer-outer layer type (Anwar et al., 2005; Nugroho \& Ando, 2001). In the point of view, the adhesive used for wood cannot be used for bamboo without modify the formulation. It must be modified for the optimizing bonding process, such as increasing of the filler amount in the glue mixture, using the liquid which has the low surface tension as the solvent in glue mixture, or adding the surfactant into the glue mixture.

The pH values of many bamboo species are on the acidic side (Ahmad, \& Kamke, 2003; Anwar et al., 2005; Chaowana et al, 2012; Malanit, Barbu, \& Frühwald, 2009). It is not different from common wood species (Fengel, \& Wegener, 1984). Moreover, it has no variation in $\mathrm{pH}$ value at the different locations on the culm. The buffer capacity is the resistance of wood to change in its $\mathrm{pH}$ level. If the wood requires a larger amount of acid catalyst to decrease the $\mathrm{pH}$ to the level required for optimum adhesive cure, it is considered as a high buffering capacity species. Many previous researchers (Ahmad \& Kamke, 2003; Anwar et al., 2005; Chaowana et al., 2012; Malanit et al., 2009) studied the buffer capacity of some bamboo species. They reported that bamboos have extremely high resistance to changes in the $\mathrm{pH}$ and weakly responds to the acid addition when compared to normal wood (Sauter, 1996). Bamboo would be considered to be the high buffer capacity specie and will require a larger amount of acid catalyst to reduce the $\mathrm{pH}$ to the optimum level which is required for a resin cure. Notable, it varies along the culm location, although the differences seem small between three locations. This may cause problems for their use as raw material in wood composite with conventional commercial resin. Some strategies, such as the use of special glue to produce boards or adjusted hot-pressing parameters, might be applied to improve resin curing and hence improve product properties too; despite the fact that the production costs will be compromised.

\subsection{The Chemical Composition of Bamboo Culm}

The chemical composition of bamboo determines its properties and influences its utilization. The main chemical constitute of bamboo are cellulose, hemicellulose and lignin, which amount to over $90 \%$ of the total mass. The minor constituents of bamboo amount to $10 \%$, which are composed of resins, tannins, waxes and inorganic salts, as presented in Table 1. 
Compared to the other wood species, the chemical compositions of bamboo are similar to those of hardwoods, except for the higher ash content. The ash of bamboo is composed of inorganic minerals, primarily silica, calcium, and potassium. Silica content is the highest in the epidermis, with very little in the nodes and is absent in the internodes. Higher ash content in some bamboo species can adversely affect the processing machinery. Additionally, bamboo contains starch, saccharide, fat and protein. The carbohydrate content of bamboo plays a negative effect for its durability and service life. The presence of large amounts of starch makes bamboo easily attacked by fungi and insects. Then, an efficiency process reducing the starch content or increasing the resistance to the insect and fungi may be needed to improve the durability of bamboo composites.

Table 1. The chemical composition of some bamboo species

\section{Chemical compositions $(\% \mathrm{w} / \mathrm{w})$}

\begin{tabular}{|c|c|c|c|c|c|c|c|}
\hline Bamboo species & 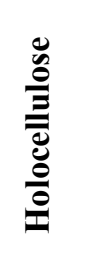 & 䔅 & $\overline{4}$ & 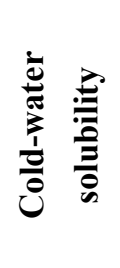 & 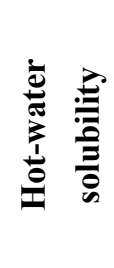 & 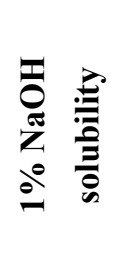 & 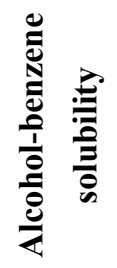 \\
\hline Dendrocalamus asper ${ }^{1}$ & 74.0 & 28.5 & 1.5 & 6.4 & 9.2 & 24.7 & 5.5 \\
\hline Phyllostachys heterocycla ${ }^{2}$ & 76.8 & 26.1 & 1.3 & - & - & - & 4.6 \\
\hline Phyllostachy nigra ${ }^{2}$ & 66.4 & 23.8 & 2.0 & - & - & - & 3.4 \\
\hline Phyllostachy reticulate $^{2}$ & 51.8 & 25.3 & 1.9 & - & - & - & 3.4 \\
\hline Phyllostachy makinoi ${ }^{3}$ & 79.9 & 25.5 & - & - & - & - & 2.6 \\
\hline Phyllostachy pubescens ${ }^{4}$ & 71.7 & 23.6 & 1.4 & - & - & - & 4.6 \\
\hline Gigantochloa scortechinii ${ }^{5}$ & 67.4 & 26.4 & 1.3 & 4.8 & 5.9 & 19.4 & 3.4 \\
\hline Bambusa clumeana ${ }^{6}$ & 69.2 & 21.6 & - & 4.3 & 7.3 & 23.3 & 3.8 \\
\hline Schizostachyum zollingeri ${ }^{6}$ & 71.6 & 21.4 & - & 4.1 & 5.1 & 24.3 & 2.5 \\
\hline
\end{tabular}

\section{Sources:}

${ }^{1}$ Kamthai (2003)

${ }^{2}$ Higuchi (1957)

${ }^{3}$ Fengel and Shao (1984)

${ }^{4} \mathrm{Li}$, Shupe, Peter, Hse and Eberhardt (2007)

${ }^{5}$ Jamaludin, Abd. Jalil, Ashari and Abd. Latif (1992)

${ }^{6}$ Nor Azah and Azmy (1991)

\subsection{The Physical Properties of Bamboo Culm}

The basic density of bamboo is in the range of $0.4-0.9 \mathrm{~g} / \mathrm{cm}^{3}$, depending mainly on the anatomical structure. In general, the location along the bamboo culm is significant for the density value. The density of bamboo increases from inner to outer part and from lower to upper part of the culm (Abd. Latif et al., 1993; Abd. Latif \& Liese, 2002; Ahmad \& Kamke, 2005; Liese, 1998; Malanit et al., 2008). Moreover, the density of nodes is higher than that of inter-nodes. When compared to the hardwoods or heavy tropical timber species which are normally used in composites panels manufacturing, the specific gravity of bamboo is relatively high. Bamboo should be used for the high-density composite products such as High Density Fiberboard. On the other hand, specific gravity of bamboo would be strongly affected by its position along the culm compared to wood species. Thus, if the 
composites are made from bamboo, a potential higher specific gravity variation should be considered.

Like wood, the dimensional shrinkage of bamboo varies in different orthotropic directions. It is clear that the tangential shrinkage is about one-half as much in radial, and much less along the longitudinal direction (Liese, 1985; Malanit et al., 2008). They also revealed relation between bamboo shrinkage and specific gravity. The shrinkage value decreases, when specific gravity value increases. When compared to the wood species, the dimensional stability of bamboo is more favorable. Moreover, the bamboo shrinkage slightly varies along the culm length. These are the favorable properties for the use of bamboo as a raw material in composite products. Thus, bamboo has higher dimensional stability than those of wood.

\subsection{The Mechanical Properties}

Similar to wood, bamboo is a heterogeneous and anisotropic material. Therefore its mechanical properties are extremely unstable related to the microstructure characteristics, culm height, culm location, density and moisture content. The mechanical properties of some bamboo species selected from several studies are presented in Table 2.

Table 2. The mechanical properties of some bamboo species

\begin{tabular}{lcccc}
\hline \multicolumn{1}{c}{ Bamboo species } & $\begin{array}{c}\text { Modulus of } \\
\text { rupture } \\
\text { (MPa) }\end{array}$ & $\begin{array}{c}\text { Modulus of } \\
\text { elasticity } \\
\text { (MPa) }\end{array}$ & $\begin{array}{c}\text { Shear strength } \\
\text { parallel to grain } \\
\text { (MPa) }\end{array}$ & $\begin{array}{c}\text { Compression } \\
\text { strength parallel } \\
\text { to grain } \\
\text { (MPa) }\end{array}$ \\
\hline Bambusa blumeana & 99.8 & 4,100 & 4.5 & 24.0 \\
Bambusa vulgaris & 62.3 & 6,100 & 4.0 & 25.3 \\
Dendrocalamus asper & 85.7 & 6,300 & 5.4 & 31.5 \\
Gigantochloa scortechinii & 52.4 & 4,800 & 4.3 & 27.0 \\
Gigantochloa levis & 78.5 & 5,100 & 4.8 & 40.0 \\
Balanocarpus hemii & 122.0 & 1,800 & 13.7 & 69.0 \\
Koompasia malaccensis & 100.0 & 1,700 & 10.0 & 54.7 \\
\hline
\end{tabular}

Source: Liese (1985).

A comparison of the mechanical properties of bamboo to those of other wood species which are used as raw material for wood composite manufacture such as Douglas-fir, Red pine, Yellow poplar, American aspen and Rubberwood (USDA Forest Service, 1999; Hong \& Sim, 1994). In general, bamboo is stronger than wood in bending strength, compression strength parallel to grain and is similar in shear strength parallel to grain. The strength of bamboo in grain direction is extremely high, especially MOR and MOE. It might be suitable as the raw material for such products as oriented structural boards which bears unidirectional load. Over the past decade, several researches, particularly in Asia, were carried out on the fundamental characteristics of bamboo and have been used as raw material for Oriented Strand Board (Lee, Bai, \& Peralta, 1996; Lee, Bai, \& Bang; 1997; Febrianto et al., 2012; Sumardi, Ono, \& Suzuki, 2007; Sumardi, Kojima, \& Suzuki, 2008), Parallel Strand Lumber (Ahmad \& Kamke, 2011) and Oriented Strand Lumber (Malanit, Barbu, \& Frühwald, 2011). Recently, one article has reported using inorganic material such as cement as the binder for OSB made from B. blumeana (Cabangon, Eusebio, Soriano, \& Evans, 2009). The product properties are able be compare to those of boards manufactured using the conventional method of manufacturing strand cement boards. The bamboo strand products are the relatively new products and the markets are still under development. However, strength properties make them a highly competitive engineered alternative to traditional lumber and will become an important forest product in the future.

In addition, bamboos have low shear strength parallel to grain. The bamboo veneers can be peeled from the 
straight culms of a thick-walled bamboo species, such as Ph. bambusoides, Ph. heterocycla, Ph. pubescens, D. latiflorus and $D$. giganteus. The bamboo veneers are processed into bamboo plywood or plybamboo with various adhesives (Anwar et al., 2009; Ganapathy, Huan-Ming, Zoolagud, Turcke, \& Espiloy; 1999; Zhang et al., 2002). Plybamboo shows the high physical and mechanical properties. It can be used as an engineering material for construction and decoration with the advantages of large and stable size, high strength and no deformation. Noticeably, phenolic treatment of veneer could improve the mechanical properties of the plybamboo. Moreover, bamboos can be easy cut into strips to produce the bamboo strip products such as glued laminated bamboo, also called Laminated Bamboo Lumber. Correal, Ramires and Yamin (2009), Nugroho and Ando (2001), Pereira and Faria (2009) reported that it shows high strength and stiffness and can be suitable material for construction and design of thinner structural elements than those made of wood. It is used as vertical columns or horizontal beams, as well as curved configuration, arched shapes. Additionally, it is also applied in the panel form for truck floor and gang planks.

According to the mechanical properties, appropriate for composite products should be considered based on their strength to weight ratio. As a result, bamboo has a low strength to weight ratio, it is not desirable for some applications because of its high specific gravity. All these complex features must be taken into concern for the bamboo utilization in the wood composite manufacturing. However, its strength (i.e., bending strength) and availability may outweigh this disadvantage.

\section{Further Research and Development}

Although bamboo shows only a slight difference in the anatomical structure and chemical composition compared to that of wood species, its morphology, macroscopic characteristics, physical and mechanical properties differ from those of wood. Moreover, the properties of bamboo depended on many factors, such as the age, culm height, growth location etc. For this reason, the further research for bamboo composite development, the property improvement and the enhancement of knowledge are necessary for assessing its suitability for bamboo composites and to decide the approximately methods, technology and equipment suitable for bamboo processing. The following recommendations for further research should determine:

1) The study about the ownership structure, tenure system, plantation area and annual production as a raw material for wood industries. These data are important to formulate it's efficiency and policies.

2) The development and study on a view to improve bamboo plantation management, as well as increase the productivity of bamboo culm.

3) Investigations on the relationship between physical/mechanical properties and anatomical characteristics of bamboo culm with different age. All can be used to consider for certain uses.

4) The high efficient methods and equipment for bamboo processing. Some specific characteristics of bamboo lead to negative influences on processing and its utilization such as node part and outer part of culm.

5) The effect of bamboo-based products on tool wear. In the basic process of wood composite manufacture, bamboo culms are processed into fibers, particles, chips or strand. The large percentage of ash content can adversely affect tools wear during machining.

6) An efficiency process reducing the starch content or increasing the resistance to the insect and fungi. In order to improve strength and durability properties of product. Chemical reagents such as acetic anhydrides solution can be used to treat the bamboo composites (Febrianto et al., 2010; Rowell \& Norimoto, 1987). The result shows that despite slight increase of production costs the dimensional stability and termite resistance of product is improved.

7) Special glue or adjusted pressing parameters to improve the resin gel time.

\section{Conclusions}

Bamboo is a kind of fast- growing and renewable resource, which is cheap and widely available. Moreover, it has the advantages of straight grain, beautiful color, high strength and toughness, and excellent abrasion resistance. Bamboo composites have similar properties to wood composites. They have been widely used in the fields of vehicle, construction, ship building, furniture, and decoration to partly take the place of wood, steel, plastic etc. than that of steel, and aging resistance is superior to that of plastic. In addition, it is easy to process and acceptable in price. Then, bamboo-based composites will become a highly competitive alternative to wood-based composites and will become an important forest based product in the future. 


\section{References}

Abd. Latif, M., \& Liese, W. (2002). Culm characteristics of two bamboos in relation to age, height and site. In A. Kumar, B. Cherla, I. V. Sastry, \& R. Rao (Eds.), Proceedings of the $5^{\text {th }}$ International Bamboo Congress and the $6^{\text {th }}$ International Bamboo Workshop (pp. 223-233). San José, Costa Rica.

Abd. Latif, M., Ariffin, W. T. W., \& Ahmad, F. (1990). Anatomical features and mechanical properties of three Malaysian bamboos. Tropical Forest Science, 2(3), 227-234.

Abd. Latif, M., Ashaari, A., Jamaludin, K., \& Mohd. Zin, J. (1993). Effects of anatomical characteristics on the physical and mechanical properties of Bambusa bluemeana. Journal Tropical Forest Science, 6(2), $159-170$.

Ahmad, M., \& Kamke, F. A. (2003). Analysis of Calcutta bamboo for structural composite materials: Surface characteristics. Wood Science and Technology, 37, 233-240. http://dx.doi.org/10.1007/s00226-003-0172-x

Ahmad, M., \& Kamke, F. A. (2005). Analysis of Calcutta bamboo for structural composite materials: Physical and mechanical properties. Wood Science and Technology, 39, 448-459. http://dx.doi.org/10.1007/s00226-005-0016-y

Ahmad, M., \& Kamke, F. A. (2011). Properties of parallel strand lumber from Calcutta bamboo (Dendrocalamus strictus). Wood Science and Technology, 45, 63-72. http://dx.doi.org/10.1007/s00226-010-0308-8

Amada, S., \& Untao, U. (2001). Fracture Properties of Bamboo. Composites Part B, 32, 451-459. http://dx.doi.org/10.1016/S1359-8368(01)00022-1

Aminuddin, M., \& Abd. Latif, M. (1991). Bamboo in Malaysia: Past, present and future research. In Proceeding $4^{\text {th }}$ International Bamboo Workshop: Bamboo in Asia and the pacific (pp. 349-354). Chaingmai, Thailand.

Anwar, U. M. K, Hamdan, H., Paridah, M. T., Mohamad Omar, M. K., Mohd Jani, S., \& Siti Rafidah, M. (2009). Mechanical properties and failure characteristic of phenolic-treated plybamboo. In the $8^{\text {th }}$ World Bamboo Conference Volume 8 (pp. 25-31). Bangkok, Thailand.

Anwar, U. M. K., Paridah, M. T., Hamdan, H., Abd Latif, M., \& Zaidon, A. (2005). Adhesion and bonding properties of plybamboo manufactured from Gigantochloa scortechinii. American Journal of Applied Sciences (Special Issue), 53-58.

Bauchongkol, P., Hiziroglu, S., Fueangvivat, V., Jarusombuti, S., \& Soontonbura, W. (2009). Bamboo (Dendrocalamus asper) as raw material for interior composite panel manufacture in Thailand. In the $8^{\text {th }}$ World Bamboo Conference Volume 8 (pp. 151-161). Bangkok, Thailand.

Cabangon, R. J., Eusebio, D. A., Soriano, F. P., \& Evans, P. D. (2009). Production of manually-oriented strand-cement board from bamboo. In the $8^{\text {th }}$ World Bamboo Conference Volume 8 (pp. 100-112). Bangkok, Thailand.

Chaowana, P., Robkorb, K., Sriwilai, S., \& Barbu, M. C. (2012). Gluability Variation of Dendrocalamus asper for Bamboo Composites. In the $9^{\text {th }}$ World Bamboo Congress Proceedings (pp. 307-315). Antwerp, Belgium.

Chapman, G. P. (1996). The biology of grasses. Department of Biochemistry and Biological Sciences, Wye College, University of London, United Kingdom.

Correan, J. F., Ramires, F., \& Yamin, L. E. (2009). Experimental study of Glued Laminated Guadua as building material: Adhesive calibration. In the $8^{\text {th }}$ World Bamboo Conference Volume 8 (pp. 16-24). Bangkok, Thailand.

Febrianto, F., Sahroni, Hidayat, W., Bakar, E. S., Know, G. J. Know, J. H., Hong, S., \& Kim, N. H. (2012). Properties of oriented strand board made from Betung bamboo (Dendrocalamus asper (Schultes.f) Backer ex Heyne). Wood Science and Technology, 46, 53-62. http://dx.doi.org/10.1007/s00226-010-0385-8

Fengel, D., \& Shao, X. (1984). A chemical and ultrastructural study of the bamboo species Phyllostachys makinoi Hay. Wood Science and Technology, 18, 103-112.

Fengel, D., \& Wegner, G. (1984). Wood: chemistry, ultrastructure, reaction. Walter de Gruyter, Berlin and New York.

Freeman, H. G. (1959). Relationship between physical and chemical properties of wood and adhesion. Forest Product Journal, 9(12), 451-458.

Ganapathy, P. M., Zhu, H. M., Zoolagud, S. S., Turcke, D., \& Espiloy, Z. B. (1999). Bamboo Panel Boards: A State-of-the-Art Review (Technical Report No. 12). The International Network for Bamboo and Rattan 
(INBAR), People's Republic of China.

Grosser, D., \& Liese, W. (1971). On the anatomy of Asian bamboos, with special reference to their vascular bundles. Wood Science and Technology, 5, 290-312. http://dx.doi.org/10.1007/BF00365061

Higuchi, H. (1957). Biochemical studies of lignin formation, III. Physiologia Plantarum, 10, 633-648. http://dx.doi.org/10.1111/j.1399-3054.1957.tb06971.x

Jamaludin, K., Abd. Jalil, H. A., Ashari, A. J., \& Abd. Latif, M. (1992).Variation in specific gravity of 1-, 2- and 3 year old Gigantochloa scortechinii (Buluh Semantan). In W. M. Wan Razali \& M. Aminuddin (Eds.). Proceeding First National Bamboo Seminar (pp. 182-185). Forest Research Institute Malaysia, Kuala Lumpur, Malaysia.

Jiang, Z. H. (2007). Bamboo and rattan in the world. People's Republic of China: China forestry publishing house.

Judziewicz, E. J., \& Sepsenwol, S. S. (2007). The world's smallest bamboo: Raddiella vanessiae (Poaceae: Bambusoideae: Olyreae), a new species from French Guiana. Journal of the Botanical Research Institute of Texas, 1, 1-7.

Kamthai, S. (2003). Alkaline sulfite pulping and ECF- bleaching of sweet bamboo (Dendrocalamus asper Backer, M.S. Thesis). Kasetsart University, Thailand.

Laemsak, N., \& Kungsuwan, K. (2000). Manufacture and properties of binderless board from Dendrocalsmus asper Backer. In L. Puangchit, B. Thaiutsa, \& S. Thamincha, (Eds.). Bamboo 2000 Proceedings of the International Symposium (pp. 175-185). Chiangmai, Thailand.

Lee, A. W. C., Bai, X., \& Bang, A. P. (1997). Flexural properties of bamboo reinforced southern fine OSB beams. Forest Product Journal, 47, 74-78.

Lee, A. W. C., Bai, X., \& Peralta, P. N. (1996). Physical and mechanical properties of strandboard made from moso bamboo. Forest Product Journal, 46(11/12), 84-88.

Lee, A. W. C., Xuesong, B., \& Perry, N. P. (1994). Selected physical and mechanical properties of giant timber bamboo grown in South Carolina. Forest Product Journal, 44(9), 40-46.

Lee, S., Shupe, T. F., \& Hse, C. Y. (2006). Mechanical and physical properties of agro-based fiberboard. Holz als Roh- und Werkstoff, 64, 74-79. http://dx.doi.org/10.1007/s00107-005-0062-z

Li, X. B., Shupe, T. F., Peter, G. F., Hse, C. Y., \& Eberhardt, T. L. (2007). Chemical changes with maturation of the bamboo species Phyllostachys pubescens. Journal of Tropical Forest Science, 19(1), 6-12.

Liese, W. (1985). Bamboos-biology, silvics, properties, utilization. Deutsche Gesellschaft für Technische Zusammenarbeit (GTZ) GmbH, Eschborn, Germany.

Liese, W. (1998). The anatomy of bamboo culms. International Network for Bamboo and Rattan, Beijing, People's Republic of China.

Lobovikov, M., Paudel, S., Piazza, M., Ren, H., \& Wu, J. (2007). World bamboo resources-A Thematic Study Prepared in the Framework of the Global Forest Resources Assessment 2005: Non-wood Forest Products 18 (Non-Wood Forest Products). Food and Agriculture Organization of the United Nations (FAO), Rome, Italy.

Malanit, P., Barbu, M. C. \& Frühwald, A. (2011). Physical and mechanical properties of oriented strand lumber made from an Asian bamboo (Dendrocalamus asper Backer). European Journal of Wood and Wood Products, 69, 27-36. http://dx.doi.org/10.1007/s00107-009-0394-1

Malanit, P., Barbu, M. C., \& Frühwald, A. (2009). The gluability and bonding quality of an Asian bamboo (Dendrocalamus asper Backer) for the production of composite lumber. Journal of Tropical Forest Science, 21(4), 361-368.

Malanit, P., Barbu, M. C., Liese, W., \& Frühwald, A. (2008). Macroscopic aspects and physical properties of Dendrocalamus asper Backer for composite panels. Journal of Bamboo and Rattan, 7(3\&4), 151-163.

Nor Aziha, M. A., \& Azmy, H. M. (1991). Preliminary study on the four Malaysian commercial bamboo species. India Bulletin, 1(2), 6-10.

Nugroho, N., \& Ando, N. (2001). Development of structural composite products made from bamboo II: fundamental properties of laminated bamboo lumber. Journal of Wood Science, 47, 237-242. http://dx.doi.org/10.1007/BF01171228 
Pereira, M. A., \& Faria, O. B. (2009). Bambu product: Mechanical characteristics of Glued Laminated Bamboo. In the $8^{\text {th }}$ World Bamboo Conference Volume 8 (pp. 135-150). Bangkok, Thailand.

Rao, A. N., Ramanatha-Rao, V., \& Williams, J. T. (1998). Priority species of bamboo and rattan. IPGRI-APO, Serdang, Malaysia.

Rowell, R. M., \& Norimoto, M. (1987). Acetylation of bamboo fiber. Mokuzai Gakkaishi, 33(11), 907-910.

Sauter, S. L. (1996). Developing composites from wheat straw. In $30^{\text {th }}$ International Particleboard/Composite Materials Symposium Proceedings (pp. 197-214). Pullman, Washington, USA.

Shao, S., Jin, Z., Wen, G., \& Iiyama, K. (2009). Thermo characteristics of steam-exploded bamboo (Phyllostachys pubescens) lignin. Wood Science and Technology, 43, 643-652. http://dx.doi.org/10.1007/s00226-009-0252-7

Shao, S., Wen, G., \& Jin, Z. (2008). Changes in chemical characteristics of bamboo (Phyllostachys pubescens) components during steam explosion. Wood Science and Technology, 42, 439-451. http://dx.doi.org/10.1007/s00226-008-0183-8

Sumardi, I., Kojima, Y., \& Suzuki, S. (2008). Effects of strand length and layer structure on some properties of strandboard made from bamboo. Journal of Wood Science, 54, 128-133. http://dx.doi.org/10.1007/s10086-007-0927-3

Sumardi, I., Ono, K., \& Suzuki, S. (2007). Effect of board density and layer structure on the mechanical properties of bamboo oriented strandboard. Journal of Wood Science, 53, 510-515. http://dx.doi.org/10.1007/s10086-007-0893-9

Sutnaun, S., Srisuwan, S., Jindasai, P., Cherdchim, B., Matan, N., \& Kyokong, B. (2005). Macroscopic and microscopic gradient structures of bamboo culms. Walailak Journal Science and Technology, 2, 81-97.

USDA Forest Service. (1999). Wood Handbook: Wood as an Engineering Material. USDA gen. Tech. Rept. FPL-GTR-133.

Wong, K. M. (1995). The bamboos of Peninsular Malaysia. Forest Research Institute Malaysia (FRIM) in collaboration with Forest Research Centre, Forestry Department, Sabah, Malaysia.

Zhang, M., Kawai, S., Yusuf, S., Imamura, Y., \& Sasaki, H. (1997). Manufacture of wood composites using lignocellulosic materials and their properties III. Properties of bamboo particleboards and dimensional stability improvement by using a steam-injection press. Mokuzai Gakkaishi, 43(4), 318-326.

Zhang, Q. S., Jiang, S. X., \& Tang, Y. Y. (2002). Industrial utilization on bamboo: Technical report No. 26. The International Network for Bamboo and Rattan (INBAR), People's Republic of China. 